\title{
Reakcja pszenicy hybrydowej na wysokie dawki azotu i nawożenie dolistne
}

\author{
Hybrid wheat response to high nitrogen application rates and foliar fertilisation
}

\author{
Jan Buczek ${ }^{\oplus}$, Marta Jańczak-Pieniążek
}

Uniwersytet Rzeszowski, Kolegium Nauk Przyrodniczych, Instytut Nauk Rolniczych, Ochrony i Kształtowania Środowiska, Zakład Produkcji Roślinnej, ul. Zelwerowicza 4, 35-601 Rzeszów,

$\triangle$ e-mail: jbuczek@ur.edu.pl

\begin{abstract}
Ścisłe doświadczenie polowe z pszenicą ozimą przeprowadzono w latach 2016-2019 w Stacji Doświadczalnej Oceny Odmian w Przecławiu. Celem badań było określenie wpływu wzrastających dawek azotu oraz nawożenia dolistnego na plonowanie, parametry architektury łanu oraz cechy jakościowe i skład mineralny ziarna hybrydowej odmiany Hybiza. Nawożenie dawką azotu $\mathrm{N}_{200}$ w porównaniu do $\mathrm{N}_{150}$ wpłynęło istotnie na zwiększenie: indeksu powierzchni liści (LAI), kąta nachylenia liści (MTA), wskaźnika zieloności liścia (SPAD), obsady kłosów na jednostce powierzchni, wylegania roślin, MTZ oraz plonu ziarna z jednostki powierzchni. Dokarmianie dolistne w porównaniu do obiektu kontrolnego skutkowało istotnym zwiększeniem takich parametrów jak: wskaźnik SPAD, MTZ oraz plon ziarna. Wyższa dawka azotu $\mathrm{N}_{200}$ wpłynęła na wzrost wartości parametrów jakościowych ziarna oraz zwiększenie w nim ilości $\mathrm{Fe}$ i $\mathrm{Cu}$. Nawożenie dolistne zwiększyło natomiast ilość Zn i Fe w ziarnie, nie wpływając na gęstość ziarna w stanie zsypnym i jego celność. Poziom plonowania oraz jakość i skład mineralny ziarna modyfikowane były zmiennymi w latach badań warunkami pogodowymi.
\end{abstract}

Słowa kluczowe: azot, dokarmianie dolistne, jakość ziarna, mikroelementy, plon, pszenica hybrydowa, SPAD

A close field experiment with winter wheat was conducted during 2016-2019, at the Experimental Station for Variety Evaluation in Przecław. The aim of the study was to determine the effect of increasing doses of nitrogen and foliar fertilization on yield, canopy architectural parameters, quality characteristics and mineral composition of grain of the hybrid cultivar Hybiza. The fertilization with $\mathrm{N}_{200}$ nitrogen dose as compared to $\mathrm{N}_{150}$ significantly increased: leaf area index (LAI), leaf tilt angle (MTA), Soil Plant Analysis Development (SPAD), spike density per area unit, plant lodging, MTZ and grain yield. Foliar feeding as compared to the control object resulted in a significant increase in such parameters as SPAD index, MTZ and grain yield. An increased dose of nitrogen $\mathrm{N}_{200}$ increased the values of quality parameters and the amount of $\mathrm{Fe}$ and $\mathrm{Cu}$. Foliar fertilisation, on the other hand, increased the amount of $\mathrm{Zn}$ and $\mathrm{Fe}$ in grain without affecting the bulk density and accuracy of grain. The yield level as well as quality and mineral composition of grain were modified by weather conditions varying in the years of the research.

Key words: nitrogen, foliar nutrition, grain quality, micronutrients, yield, hybrid wheat, SPAD

Na wielkość i jakość plonu ziarna pszenicy wpływają zarówno czynniki odmianowe, agrotechniczne jak i środowiskowe (Klikocka i in. 2016, Jaskulska i in. 2018). Nawożenie azotem jest podstawowym czynnikiem plonotwórczym zwiększającym krzewienia produkcyjne oraz odgrywającym ważną rolę w kształtowaniu jakości białka w ziarnie (Podolska 2008, Faizy $\mathrm{i}$ in. 2017). Uzyskanie wysokich oraz jakościowo dobrych plonów pszenicy jest możliwe wówczas gdy w okresie wegetacji dawki azotu dostosowane są do potrzeb pokarmowych i faz rozwojowych roślin (Kulig i in. 2009, Skudra i Ruza 2016). W systemie zrównoważonego nawożenia pszenicy efekty zastosowanych dawek azotu są widoczne w przypadku zbilansowanego stosowania pozostałych składników pokarmowych. Dokarmianie dolistne jest jedną z metod uzupełnienia niedoborów składników odżywczych, w tym również mikroelementów, których aplikacja na ogół korzystnie wpływa na wielkość plonu pszenicy, skład mineralny ziarna oraz jego cechy technologiczne (Gąsiorowska i Makarewicz 2008, Zeidan i in. 2010, Jarecki i Bobrecka 2011). Odmiany mieszańcowe pszenicy, w porównaniu z populacyjnymi, charakteryzują się wyższym plonem ziarna i większą tolerancją na uprawę w monokulturze oraz stresowe warunki klimatyczne (Witford $i$ in. 2013). Jednak wpływ czynników środowiskowo-agrotechnicznych na jakość technologiczną i skład mineralny ziarna tych pszenic jest mało poznany (Zhao i in. 2013, Mühleisen i in. 2014). 
Celem pracy było ocena wpływu wzrastających dawek azotu oraz nawożenia dolistnego na plonowanie, parametry architektury łanu oraz cechy jakościowe i skład chemiczny ziarna pszenicy hybrydowej odmiany Hybiza. W badaniach założono, że doglebowe nawożenie azotem bardziej zmodyfikuje wielkość i jakość uzyskanego plonu ziarna niż nawożenie dolistne mikroelementami.

\section{Material i Metody}

Ścisłe doświadczenie polowe przeprowadzono w 3 sezonach wegetacyjnych w latach 2016-2019 w Stacji Doświadczalnej Oceny Odmian w Przecławiu $\left(50^{\circ} 11^{\prime} \mathrm{N}, 21^{\circ} 29^{\prime} \mathrm{E}\right)$. Doświadczenie dwuczynnikowe założono w układzie równoważnych bloków w czterech powtórzeniach a powierzchnia poletka do zbioru wynosiła $16 \mathrm{~m}^{2}$.

Pierwszym badanym czynnikiem było nawożenia azotem (saletra amonowa 34\%) w dawkach: $\mathrm{N}_{150}-150 \mathrm{~kg}$, ha-1 $(60 \mathrm{~kg}+50 \mathrm{~kg}+40 \mathrm{~kg})$ i $\mathrm{N}_{200}-200 \mathrm{~kg} \mathrm{ha}^{-1}(60 \mathrm{~kg}+80 \mathrm{~kg}+40 \mathrm{~kg}+20 \mathrm{~kg})$. Nawożenie azotem w przypadku dawki $\mathrm{N}_{150}$ wykonano na wiosnę (po ruszeniu wegetacji) oraz w okresie wegetacji w fazach strzelania $\mathrm{w}$ źdźbło (32-33 BBCH) i liścia flagowego (39 BBCH).

Natomiast dawkę $\mathrm{N}_{200}$ aplikowano na wiosnę (po ruszeniu wegetacji) i w okresie wegetacji w fazach strzelania w źdźbło (32-33 BBCH), liścia flagowego (39 $\mathrm{BBCH})$ i kłoszenia $(54-56 \mathrm{BBCH})$. Drugim czynnikiem był: Fomix ${ }^{2}$ - nawóz dolistny FoliQ Mikromix (Agrii Sp. z.o.o., Polska) oraz $\mathrm{C}^{1}$ - obiekt kontrolny (bez nawożenia dolistnego). Nawóz dolistny FoliQ Mikromix zawierał $\left(\mathrm{w} \mathrm{g} \cdot \mathrm{dm}^{3}\right)$ następujące makroelementy: $\mathrm{N}-120 ; \mathrm{K}_{2} \mathrm{O}-150$; $\mathrm{MgO}-45 \mathrm{i} \mathrm{SO}_{3}-75$ oraz mikroelementy: $\mathrm{B}-$ 4,35; $\mathrm{Cu}-7,25 ; \mathrm{Fe}-14,50 ; \mathrm{Mn}-21,75 ; \mathrm{Mo}-0,15$ i $\mathrm{Zn}-14,50$. Nawożenie dolistne FoliQ Mikromix $\mathrm{w}$ dawce $1.0 \mathrm{dm}^{3} \mathrm{ha}^{-1}$, wykonano trzykrotnie w fazach: krzewienia (19 $\mathrm{BBCH})$, strzelania w źdźbło (39 $\mathrm{BBCH})$ oraz kłoszenia $(55 \mathrm{BBCH})$. Pszenicę hybrydową odmiany Hybiza (Saaten Union Recherche SAS, Francja) uprawiano po rzepaku ozimym, wysiewając co roku $2,0 \mathrm{mln}$ ziaren $\cdot \mathrm{ha}^{-1} \mathrm{w}$ rozstawie rzędów $12,5 \mathrm{~cm}$, na głębokość 3-4 cm.

Doświadczenie założono na madach brunatnych o składzie granulometrycznym pyłu ilastego (2016/2017 i 2018/2019) i glin ilastych (2017/2018). Glebę według WRB (2015) zaliczano do Fluvic Cambisols (CMfv). Analizę próbek gleby przeprowadzono $\mathrm{W}$ akredytowanym laboratorium Okręgowej Stacji Chemiczno-Rolniczej w Rzeszowie, zgodnie z polskimi normami. Odczyn gleby był lekko kwaśny a zawartość próchnicy wynosiła
1,57\%. Zawartość $\mathrm{N}_{\min }$ była niska, przyswajalnego fosforu i potasu wysoka a magnezu i mikroelementów średnia (tab. 2).

Nawożenie fosforem (superfosfat potrójny $46 \%$ ) $\mathrm{w}$ dawce $100 \mathrm{~kg} \mathrm{ha}^{-1} \mathrm{i}$ potasem (sól potasowa $60 \%$ ) w dawce $150 \mathrm{~kg}^{\text {} ~} \mathrm{ha}^{-1}$ zastosowano jednorazowo jesienią. Zachwaszczenie regulowano wiosną, stosując Maraton 375 SC (pendimetalina, izoproturon) i Huzar Activ 387 OD (jodosulfuron metylosodowy, 2,4-D) w dawkach 4,0 i 1,0 $\mathrm{dm}^{3}$ ha $^{-1}$. Ponadto do ochrony roślin wykorzystano fungicydy Soligor 425 EC (protiokonazol, spiroksamina, tebukonazol) i Artea 330 EC (propikonazol, cyprokonazol) - w dawkach 1,0 i 0,5 $\mathrm{dm}^{3} \mathrm{ha}^{-1}$, insektycydy Bi 58 Nowy EC $400\left(0,5 \mathrm{dm}^{3} \mathrm{ha}^{-1}\right.$, dimetoat $)$ i Karate Zeon 050 CS $\left(0,1 \mathrm{dm}^{3} \mathrm{ha}^{-1}\right.$, lambda-cyhalotryna) oraz retardant wzrostu Moddus 250 EC $\left(0,4 \mathrm{dm}^{3} \mathrm{ha}^{-1}\right.$, trineksapak etylu). Preparaty stosowano zgodnie $\mathrm{z}$ instrukcją producenta w odpowiednich fazach rozwojowych pszenicy.

Pszenicę zebrano $\mathrm{w}$ fazie pełnej dojrzałości ziarna (89-92 BBCH) za pomocą kombajnu poletkowego. Uzyskany plon ziarna przeliczono na 1 ha przy $14 \%$ wilgotności.

Obsadę kłosów policzono na powierzchni $1 \mathrm{~m}^{2}$ przed zbiorem. Z każdego poletka pobrano po 20 kłosów i oznaczono liczbę ziaren z kłosa oraz masę tysiąca ziaren.

Pomiary chlorofilomierzem SPAD 502P (Konica Minolta) wykonywano w fazie dojrzałości mlecznej $(75 \mathrm{BBCH})$ na 30 liściach flagowych. W tej samej fazie rozwojowej w godzinach porannych dokonano pomiaru indeksu powierzchni liści aparatem LAI 2000 firmy LI-COR (USA). Wyleganie roślin przed zbiorem podano $\mathrm{w}$ skali $9^{\circ}$, gdzie $1^{\circ}$ oznaczało całkowite wylegnięcie łanu, zaś $9^{\circ}$ brak wylegania. Zawartość białka ( $\mathrm{N}$ x 6.25) określono metodą Kjeldahla, przy użyciu zestawu do mineralizacji Büchi Scrubber B414 i zestawu destylacyjnego Büchi 324 (PN-EN ISO 20483), ilość glutenu mokrego na aparacie Glutomatic 2200 (PN-A-74042), wskaźnik sedymentacyjny metodą Zeleny'ego (PN-EN ISO 5529) oraz liczbę opadania metodą Hagberga-Pertena (PN-EN ISO 3093). Gęstość ziarna w stanie zsypnym zsypnym oznaczono za pomocą gęstościomierza wyposażonego w cylinder $1000 \mathrm{ml}$ (PN-EN ISO 7971-3) a masę 1000 ziaren według PN-68/R-74017. Celność ziarna wyliczono po wcześniejszym wykonaniu jego separacji na próbce $100 \mathrm{~g}$ ziarna, przy czasie wytrząsania 3 minuty i wilgotności ziarna 14,5\%, na separatorze laboratoryjnym Sortimat Pfeuffer. W celu oznaczenia mikroelementów próbki ziarna zmineralizowano w mieszaninie kwasów $\mathrm{HNO}_{3}$, 


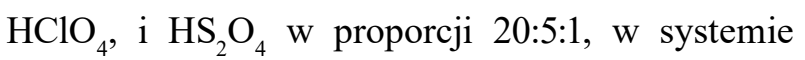
otwartym $\mathrm{w}$ bloku grzejnym Tecator. W otrzymanych próbkach oznaczono zawartości $\mathrm{Zn}, \mathrm{Mn}$, $\mathrm{Cu}$ i Fe metodą atomowej spektrometrii absorpcyjnej (AAS), stosując aparat Hitachi Z-2000 (Japonia).

Warunki pogodowe $w$ latach prowadzenia badań były zróżnicowane (tab. 1). W okresie jesiennej wegetacji roślin warunki pogodowe były korzystne, jedynie w sezonie 2018/2019 suma opadów w porównaniu do wielolecia była niższa o 43,3 $\mathrm{mm}$. Średnia temperatura w czasie spoczynku zimowego była wyższa od wieloletniej z wyjątkiem sezonu 2016/2017. Suma opadów $\mathrm{w}$ okresie wegetacji wiosenno-letniej w sezonach 2016/2017 i 2018/2019 była wyższa niż w sezonie 2017/2018. Jednak w sezonie 2018/2019 w porównaniu do wielolecia w czerwcu i lipcu wystapił niedobór opadów a w czerwcu wyższa średnia temperatura.

Wyniki badań opracowano statystycznie za pomocą analizy wariancji (ANOVA), wykorzystując program statystyczny Analwar-5.1FR oraz Statistica 9.0 (StatSoft, Tulsa). Istotność różnic między obiektami weryfikowano testem Tukey'a $(L S D)$, na poziomie istotności $p \leq 0.05$.

Tabela 1

Podstawowe cechy gleby przed doświadczeniem $(0-35 \mathrm{~cm})$.

Table 1

Basic soil characteristics prior to the experiment $(0-35 \mathrm{~cm})$.

\begin{tabular}{|c|c|c|c|}
\hline \multirow{3}{*}{$\begin{array}{l}\text { Cecha } \\
\text { Traits }\end{array}$} & \multicolumn{3}{|c|}{$\begin{array}{l}\text { Lata } \\
\text { Years }\end{array}$} \\
\hline & $2016 / 2017$ & $2017 / 2018$ & $2018 / 2019$ \\
\hline & \multicolumn{3}{|c|}{ Value } \\
\hline $\mathrm{pH}$ in $\mathrm{KCl}$ & 7,42 & 6,10 & 6,00 \\
\hline $\mathrm{C}$ org. $\left(\mathrm{g} \cdot \mathrm{kg}^{-1}\right)$ & 21,6 & 20,5 & 19,8 \\
\hline \multirow[t]{2}{*}{$\mathrm{N}_{\min }\left(\mathrm{kg} \cdot \mathrm{ha}^{-1}\right)$} & 60,1 & 53,4 & 65,0 \\
\hline & \multicolumn{2}{|c|}{$\begin{array}{l}\text { Zawartość składników przyswajalnych } \\
\text { Content of available nutrients }\left(\mathrm{mg} \mathrm{kg}^{-1}\right)\end{array}$} & \\
\hline$P$ & 204,0 & 129,5 & 73,0 \\
\hline $\mathrm{K}$ & 270,1 & 180,4 & 250,3 \\
\hline $\mathrm{Mg}$ & 127,5 & 140,1 & 229,6 \\
\hline $\mathrm{Fe}$ & 2289,0 & 2523,0 & 2222,0 \\
\hline $\mathrm{Zn}$ & 14,2 & 13,3 & 12,8 \\
\hline $\mathrm{Mn}$ & 389,0 & 251,4 & 265,1 \\
\hline $\mathrm{Cu}$ & 6,0 & 6,2 & 6,4 \\
\hline
\end{tabular}

Warunki pogodowe w czasie wegetacji pszenicy ozimej.

Weather conditions for three growing seasons.

\begin{tabular}{|c|c|c|c|c|c|c|c|c|}
\hline \multirow{2}{*}{$\begin{array}{l}\text { Rok } \\
\text { Year }\end{array}$} & \multirow[t]{2}{*}{ A } & \multirow[t]{2}{*}{$\mathrm{W}$} & \multicolumn{5}{|c|}{$\begin{array}{l}\text { Wegetacja wiosenno-letnia } \\
\text { Spring-summer vegetation period }\end{array}$} & \multirow[t]{2}{*}{$\mathrm{S} / \mathrm{H}$} \\
\hline & & & III & IV & $\mathrm{V}$ & VI & VII & \\
\hline \multicolumn{9}{|c|}{ Temperatura - Temperature $\left({ }^{\circ} \mathrm{C}\right)$} \\
\hline $2016 / 2017$ & 7,2 & $-2,9$ & 4,9 & 7,1 & 12,5 & 17,4 & 17,9 & 6,6 \\
\hline $2017 / 2018$ & 8,1 & $-0,8$ & $-2,4$ & 12,2 & 12,6 & 16,9 & 17,7 & 7,5 \\
\hline $2018 / 2019$ & 8,6 & $-0,3$ & 3,2 & 7,8 & 15,4 & 20,8 & 18,5 & 7,9 \\
\hline $1956-2015$ & 8,2 & $-1,7$ & 3,3 & 7,9 & 13,9 & 16,9 & 18,9 & 7,3 \\
\hline \multicolumn{9}{|c|}{ Opady - Rainfall (mm) } \\
\hline $2016 / 2017$ & 234,2 & 68,0 & 38,4 & 78,3 & 111,9 & 41,6 & 44,4 & 616,8 \\
\hline $2017 / 2018$ & 231,4 & 75,3 & 40,9 & 15,7 & 68,8 & 47,4 & 108,3 & 587,8 \\
\hline $2018 / 2019$ & 93,5 & 88,2 & 24,3 & 62,1 & 182 & 19,2 & 45,1 & 514,4 \\
\hline 1956-2015 & 136,8 & 104,0 & 35,2 & 49,8 & 38,1 & 82,1 & 99,2 & 545,2 \\
\hline
\end{tabular}

A-wegetacja jesienna, autumn vegetation period (IX-XI), W-spoczynek zimowy, winter rest (XII-II), S/H-średnia, mean/suma, sum (od siewu do zbioru, from sowing to harvest). 


\section{Wyniki i Dyskusja}

Zastosowanie wyższej dawki azotu $-\mathrm{N}_{200}$ wpłynęło istotnie na wzrost plonu ziarna (o 0,61 tha $^{-1}$ ) pszenicy w porównaniu do dawki $\mathrm{N}_{150}$ (tab. 3). Wzrost plonowania pszenicy pod wpływem wyższych dawek azotu stwierdzili także Klikocka $\mathrm{i}$ in (2016) i Faizy i in. (2017). Testowana pszenica najwyżej plonowała $\mathrm{w}$ sezonie 2017/2018 zaś najsłabiej w 2018/2019, co spowodowane było niedoborem opadów i wysokimi temperaturami pod koniec wegetacji pszenicy. Svečnjak i in. (2013) podają, że na plonowanie pszenicy decydujący wpływ ma genotyp odmiany i lata badań, natomiast mniejszy interakcja odmiany i nawożenia azotem. Dokarmianie dolistne oddziaływało istotnie na przyrost plonu ziarna w porównaniu do obiektu kontrolnego, średnio o 0,35 tha $^{-1}$. Wzrost plonu ziarna po zastosowaniu FoliQ Mikromix na tle dawki $\mathrm{N}_{150}$ w odniesieniu do kontroli wyniósł $3,3 \%$, a $\mathrm{z}$ dawką $\mathrm{N}_{200}$ $4,8 \%$. Również w badaniach Jareckiego i Bobreckiej-Jamro (2011) dokarmianie dolistne korzystnie wpłynęło na przyrost plonu ziarna w odniesieniu do kontroli, przy czym istotną różnicę uzyskano po łącznej aplikacji mocznika z nawozem dolistnym Mikrokomplex.

Zastosowanie dawki azotu $\mathrm{N}_{200}$ W porównaniu do $\mathrm{N}_{150}$ wpłynęło istotnie na zwiększenie liczby kłosów na jednostce powierzchni nie różnicując statystycznie istotnie liczby ziaren w kłosie i MTZ. Również Podolska (2008) wykazała, że nawożenie azotem zwiększa liczbę kłosów na $1 \mathrm{~m}^{-2}$, przy czym jest on uzależniony od przebiegu pogody. Dokarmiane dolistne natomiast wpłynęło jedynie na istotny wzrost dorodności ziarna w odniesieniu do kontroli o 4,3\% (tab. 3).

Wskaźniki LAI oraz MTA mierzone w fazie dojrzałości mlecznej (75 BBCH) wynosiły średnio $4,43 \mathrm{~m}^{2} \cdot \mathrm{m}^{-2}$ oraz $46^{\circ}$ (tab. 4). Parametry te były istotnie wyższe po zastosowaniu dawki azotu $\mathrm{N}_{200}$ W odniesieniu do $\mathrm{N}_{150}$, a różnica wynosiła odpowiednio $1,23 \mathrm{~m}^{2} \mathrm{~m}^{-2}$ i $5^{\circ}$. Dokarmianie dolistne nie modyfikowało istotnie omawianych indeksów. W badaniach Baveca i in. (2007) oraz Olsena i Weinera (2007) wykazano, że na powierzchnię liściową pszenicy korzystnie wpływa nawożenie azotem i gęstość siewu. Natomiast w badaniach Biskupskiego i in. (2007) nad pszenicą jarą, wskaźnik LAI był zróżnicowany istotnie tylko w latach i nie zależał od zastosowanej dawki azotu. Jarecki $i$ in. (2014) po zastosowaniu intensywnego poziomu agrotechniki, w porównaniu do niższego, uzyskali wyższe wartości nie tylko wskaźnika MTA, ale również LAI i SPAD. W prezentowanych badaniach własnych wskaźnik zieloności liścia (SPAD) przyjął istotnie większe wartości pod wpływem zastosowania wyższej dawki azotu $\mathrm{N}_{200}$ w porównaniu do $\mathrm{N}_{150}$. Także dokarmianie dolistne wpłynęło istotnie

Tabela 3

Table 3

Plon oraz wybrane elementy struktury plonu pszenicy hybrydowej (średnia z lat 2016-2019). Yield and selected elements of the yield structure of hybrid wheat (mean for 2016-2019).

\begin{tabular}{|c|c|c|c|c|c|}
\hline \multicolumn{2}{|c|}{$\begin{array}{l}\text { Czynnik } \\
\text { Treatment }\end{array}$} & \multirow{2}{*}{$\begin{array}{l}\text { Plon ziarna } \\
\text { Grain yield } \\
\left(\mathrm{t}^{\left.-h^{-1}\right)}\right.\end{array}$} & \multirow{2}{*}{$\begin{array}{c}\text { Liczba kłosów } \\
\text { Number of ears per } \\
1 \mathrm{~m}^{2}\end{array}$} & \multirow{2}{*}{$\begin{array}{c}\text { Liczba ziaren } \\
\text { w kłosie } \\
\text { Number of grains } \\
\text { per ear }\end{array}$} & \multirow{2}{*}{$\begin{array}{c}\text { Masa } 1000 \text { ziaren } \\
1000 \text { grains weight } \\
(\mathrm{g})\end{array}$} \\
\hline $\begin{array}{l}\text { Dawka azotu } \\
\mathrm{N} \text { rate }\left(\mathrm{kg} \mathrm{ha}^{-1}\right)\end{array}$ & $\begin{array}{l}\text { Nawożenie dolistne } \\
\text { Foliar fertilization } \\
\qquad\left(\mathrm{dm}^{3} \cdot \mathrm{ha}^{-1}\right)\end{array}$ & & & & \\
\hline \multirow{2}{*}{$\mathrm{N}_{150}$} & $\mathrm{C}^{1}$ & $8,25^{\mathrm{d}}$ & $550,6^{\mathrm{b}}$ & $35,6^{\mathrm{a}}$ & $42,3^{a}$ \\
\hline & Fomix $^{2}$ & $8,52^{\mathrm{c}}$ & $552,2^{\mathrm{b}}$ & $34,8^{\mathrm{a}}$ & $44,2^{\mathrm{b}}$ \\
\hline \multirow{2}{*}{$\mathrm{N}_{200}$} & $\mathrm{C}^{1}$ & $8,79^{\mathrm{b}}$ & $568,7^{\mathrm{a}}$ & $36,1^{\mathrm{a}}$ & $43,0^{\mathrm{a}}$ \\
\hline & Fomix $^{2}$ & $9,21^{\mathrm{a}}$ & $576,9^{\mathrm{a}}$ & $35,9^{\mathrm{a}}$ & $45,0^{\mathrm{b}}$ \\
\hline \multicolumn{2}{|c|}{$\mathrm{N}_{150}$} & $8,39^{b}$ & $551,4^{\mathrm{b}}$ & $35,2^{\mathrm{a}}$ & $43,3^{\mathrm{a}}$ \\
\hline \multicolumn{2}{|c|}{$\mathrm{N}_{200}$} & $9,00^{\mathrm{a}}$ & $572,8^{\mathrm{a}}$ & $36,0^{\mathrm{a}}$ & $44,0^{\mathrm{a}}$ \\
\hline \multicolumn{2}{|c|}{$\mathrm{C}^{1}$} & $8,52^{b}$ & $559,7^{\mathrm{a}}$ & $35,9^{\mathrm{a}}$ & $42,7^{b}$ \\
\hline \multicolumn{2}{|c|}{ Fomix $^{2}$} & $8,87^{\mathrm{a}}$ & $564,6^{\mathrm{a}}$ & $35,4^{\mathrm{a}}$ & $44,6^{\mathrm{a}}$ \\
\hline \multicolumn{2}{|c|}{$2016 / 2017$} & $8,75^{\mathrm{b}}$ & $565,9^{\mathrm{b}}$ & $35,9^{\mathrm{ab}}$ & $43,7^{\mathrm{ab}}$ \\
\hline \multicolumn{2}{|c|}{$2017 / 2018$} & $9,12^{\mathrm{a}}$ & $580,3^{\mathrm{a}}$ & $36,8^{\mathrm{a}}$ & $44,6^{\mathrm{a}}$ \\
\hline \multicolumn{2}{|c|}{$2018 / 2019$} & $8,20^{\mathrm{b}}$ & $540,2^{\mathrm{c}}$ & $34,1^{b}$ & $42,5^{\mathrm{b}}$ \\
\hline \multicolumn{2}{|c|}{ Średnia - Mean } & 8,69 & 562,1 & 35,6 & 43,6 \\
\hline
\end{tabular}

$C^{l}$ - kontrola - control, Fomix² - FoliQ Mikromix, Wartości oznaczone tą samą literą nie różnią się istotnie - Different letters in the same column indicate significant differences, $\mathrm{p} \leq 0.05$ 
Pomiary polowe lanu pszenicy hybrydowej (średnia z lat 2016-2019).

Field measurements of the stand of hybrid wheat (mean for 2016-2019).

\begin{tabular}{|c|c|c|c|c|c|}
\hline \multicolumn{2}{|c|}{$\begin{array}{l}\text { Czynnik } \\
\text { Treatment }\end{array}$} & \multirow{2}{*}{$\begin{array}{c}\text { LAI } \\
\left(\mathrm{m}^{2} \mathrm{~m}^{-2}\right)\end{array}$} & \multirow[b]{2}{*}{$\begin{array}{l}\text { MTA } \\
\left({ }^{\circ}\right)\end{array}$} & \multirow[b]{2}{*}{ SPAD } & \multirow{2}{*}{$\begin{array}{l}\text { Stopień wylegania } \\
\text { Lodging degree }\end{array}$} \\
\hline $\begin{array}{l}\text { Dawka azotu } \\
\mathrm{N} \text { rate }\left(\mathrm{kg} \mathrm{ha}^{-1}\right)\end{array}$ & $\begin{array}{c}\text { Nawożenie dolistne } \\
\text { Foliar fertilization } \\
\left(\mathrm{dm}^{3} \mathrm{ha}^{-1}\right)\end{array}$ & & & & \\
\hline \multirow{2}{*}{$\mathrm{N}_{150}$} & $\mathrm{C}^{1}$ & $3,75^{\mathrm{b}}$ & $43^{\mathrm{b}}$ & $24,2^{\mathrm{b}}$ & $8,4^{\mathrm{a}}$ \\
\hline & Fomix ${ }^{2}$ & $3,89^{\mathrm{b}}$ & $44^{\mathrm{b}}$ & $2,6^{\mathrm{a}}$ & $8,0^{\mathrm{a}}$ \\
\hline \multirow{2}{*}{$\mathrm{N}_{200}$} & $\mathrm{C}^{1}$ & $4,85^{\mathrm{a}}$ & $47^{\mathrm{a}}$ & $30,2^{\mathrm{c}}$ & $7,6^{\mathrm{b}}$ \\
\hline & Fomix $^{2}$ & $5,24^{\mathrm{a}}$ & $50^{\mathrm{a}}$ & $32,2^{\mathrm{d}}$ & $7,8^{\mathrm{b}}$ \\
\hline $\mathrm{N}_{150}$ & & $3,82^{\mathrm{b}}$ & $44^{\mathrm{b}}$ & $26,4^{\mathrm{b}}$ & $8,2^{\mathrm{a}}$ \\
\hline $\mathrm{N}_{200}$ & & $5,05^{\mathrm{a}}$ & $49^{a}$ & $31,2^{\mathrm{a}}$ & $7,7^{\mathrm{b}}$ \\
\hline $\mathrm{C}^{1}$ & & $4,30^{\mathrm{a}}$ & $45^{\mathrm{a}}$ & $27,2^{\mathrm{b}}$ & $8,0^{\mathrm{a}}$ \\
\hline Fomix $^{2}$ & & $4,57^{\mathrm{a}}$ & $47^{\mathrm{a}}$ & $30,4^{\mathrm{a}}$ & $7,9^{\mathrm{a}}$ \\
\hline $2016 / 2017$ & & $4,55^{\mathrm{b}}$ & $48^{\mathrm{a}}$ & $28,6^{\mathrm{a}}$ & $8,4^{\mathrm{a}}$ \\
\hline $2017 / 2018$ & & $4,80^{\mathrm{a}}$ & $45^{\mathrm{b}}$ & $31,8^{\mathrm{a}}$ & $7,9^{\mathrm{b}}$ \\
\hline 2018/2019 & & $3,95^{\mathrm{c}}$ & $44^{\mathrm{b}}$ & $25,9^{\mathrm{b}}$ & $7,6^{\mathrm{b}}$ \\
\hline Średnia - Mean & & 4,43 & 46 & 28,8 & 8,0 \\
\hline
\end{tabular}

$C^{l}$ - kontrola - control, Fomix² - FoliQ Mikromix, Wartości oznaczone tą samą literą nie różnią się istotnie - Different letters in the same column indicate significant differences, $\mathrm{p} \leq 0.05$

na zwiększenie wartości wskaźnika SPAD. Według Panasiewicz i in. (2009) oraz Sulewskiej i in. (2011) nawożenie azotem oraz wapniowo-magnezowe poprawia stan odżywienia zbóż, przy czym Fotyma i Bezduszniak (2000) zwracają uwagę, że pogłówna aplikacja wyższych dawek azotu może powodować obniżenie wartości wskaźnika zieloności liścia SPAD.

Jak podaje Kara i Mujdeci (2010) również czynnik pogodowy, w tym wysokość opadów może modyfikować zawartość chlorofilu. W wilgotniejszych sezonach 2016/2017 i 2017/2018 wskaźnik SPAD osiągnął $\mathrm{w}$ prezentowanych badaniach własnych istotnie większą wartość niż w sezonie 2018/2019 o niższej sumie opadów. Pod wpływem wyższej dawki azotu $\mathrm{N}_{200}$ w porównaniu do $\mathrm{N}_{150}$ wyleganie roślin było istotnie wyższe, natomiast aplikacja dolistna nie miała wpływu na wartość tego czynnika powodującego straty w plonach zbóż. W badaniach Kuliga i in. (2009) stopień wylegania pszenicy mieścił się w zakresie od 4,7 do $7,1^{\circ}$ i zależał od technologii uprawy oraz porażenia roślin przez choroby.

Zwiększenie dawki azotu ze 150 do $200 \mathrm{~kg} \cdot \mathrm{ha}^{-1}$ istotnie wpłynęło na wzrost wartości parametrów jakościowych ziarna: zawartości białka ogólnego o $8,4 \%$, ilości glutenu o $14,2 \%$, wskaźnika sedymentacji Zeleny'ego o 13,0\%, gęstości ziarna w stanie zsypnym o $3,8 \%$ oraz celności ziarna o 3,2\% (tab. 5). Podolska (2008) podaje, że istotnym elementem technologii uprawy pszenicy powodującym wzrost zawartości białka w ziarnie pszenicy jest dawka azotu i sposób jej aplikacji. Skudra i Ruza (2016) oraz Jaskulska i in. (2018) stosując dawki azotu, odpowiednio od 85 do $175 \mathrm{~kg} \cdot \mathrm{ha}^{-1}$ i od 100 do $200 \mathrm{~kg} \cdot \mathrm{ha}^{-1}$ uzyskali korzystniejsze cechy jakościowe ziarna pszenicy.

W prezentowanych badaniach własnych dokarmianie dolistne w porównaniu do obiektu kontrolnego korzystniej wpływało na analizowane cechy jakościowe ziarna (zawartości białka i glutenu, wartości wskaźnika sedymentacji) za wyjątkiem gęstości ziarna w stanie zsypnym i celności ziarna. Zeidan i in. (2010) potwierdzili wpływ dolistnie zastosowanych mikroelementów na wzrost zawartości w ziarnie pszenicy białka ogólnego. Natomiast Jarecki i in. (2016) nie wykazali takiej zależności, a dokarmianie dolistne skutkowało jedynie wzrostem zawartości popiołu w ziarnie w porównaniu do kontroli.

Jak wynika z badań Rharrabtiego i in. (2003) oraz Podolskiej (2008) parametry jakościowe ziarna są również determinowane warunkami środowiskowymi, co potwierdzają prezentowane badania.

Ziarno zebrane $\mathrm{w}$ sezonie wegetacyjnym 2018/2019, charakteryzującym się wyższą od wielolecia temperaturą powietrza i opadami o wysokości $514,4 \mathrm{~mm}$, miało niższą celność, lecz odznaczało się 
wyższymi wartościami zwłaszcza zawartości białka ogólnego oraz ilości glutenu. Nadmiar opadów, jaki wystąpił w sezonie 2016/2017 spowodował istotne obniżenie cech jakościowych ziarna (białko, gluten, wskaźnik sedymentacji, gęstość ziarna w stanie zsypnym).
Wraz ze zwiększaniem dawki azotu, ilość Fe i $\mathrm{Cu}$ w ziarnie pszenicy istotnie wzrastała i była najwyższa po aplikacji dawki $\mathrm{N}_{200}$. W porównaniu do ilości tych mikroelementów w ziarnie pszenicy nawożonej dawką $\mathrm{N}_{150}$ różnice wynosiły odpowiednio: 5,1 i $24,1 \%$ (tab. 6 ).

Tabela 5

Parametry jakości ziarna pszenicy hybrydowej (średnia z lat 2016-2019).

Table 5 Quality parameters of grain of hybrid wheat (mean for 2016-2019).

\begin{tabular}{|c|c|c|c|c|c|c|}
\hline \multicolumn{2}{|c|}{$\begin{array}{l}\text { Czynnik } \\
\text { Treatment }\end{array}$} & \multirow{2}{*}{$\begin{array}{l}\text { Zawartość } \\
\text { białka } \\
\text { Total protein } \\
\left(\mathrm{g} \cdot \mathrm{kg}^{-1}\right)\end{array}$} & \multirow{2}{*}{$\begin{array}{c}\text { Ilość } \\
\text { glutenu } \\
\text { Gluten content } \\
(\%)\end{array}$} & \multirow{2}{*}{$\begin{array}{c}\text { Wskaźnik } \\
\text { sedymentacji } \\
\text { Zeleny’s index } \\
\text { (ml) }\end{array}$} & \multirow{2}{*}{$\begin{array}{c}\text { Gęstość ziarna } \\
\text { w stanie zsypnym } \\
\text { Test weight }(\mathrm{kg} \\
\left.\mathrm{hl}^{-1}\right)\end{array}$} & \multirow{2}{*}{$\begin{array}{c}\text { Celność ziarna } \\
\text { Grain } \\
\text { of uniformity } \\
(\%)\end{array}$} \\
\hline $\begin{array}{l}\text { Dawka azotu } \\
\mathrm{N} \text { rate }\left(\mathrm{kg} \cdot \mathrm{ha}^{-1}\right)\end{array}$ & $\begin{array}{l}\text { Nawożenie } \\
\text { dolistne } \\
\text { Foliar fertilization } \\
\quad\left(\mathrm{dm}^{3} \cdot \mathrm{ha}^{-1}\right)\end{array}$ & & & & & \\
\hline \multirow{2}{*}{$\mathrm{N}_{150}$} & $\mathrm{C}^{1}$ & $117,8^{\mathrm{de}}$ & $23,7^{\mathrm{d}}$ & $37,3^{\text {ed }}$ & $73,5 b^{c}$ & $90^{\mathrm{b}}$ \\
\hline & Fomix $^{2}$ & $121,7^{\mathrm{c}}$ & $25,5^{\mathrm{c}}$ & $41,2^{b}$ & $75,8^{\mathrm{b}}$ & $92^{\mathrm{a}}$ \\
\hline \multirow{2}{*}{$\mathrm{N}_{200}$} & $\mathrm{C}^{1}$ & $129,0^{\mathrm{b}}$ & $27,6^{\text {be }}$ & $43,8^{\mathrm{cd}}$ & $77,4^{\mathrm{a}}$ & $93^{\mathrm{a}}$ \\
\hline & Fomix $^{2}$ & $132,7^{\mathrm{a}}$ & $29,7^{\mathrm{a}}$ & $46,6^{\mathrm{a}}$ & $78,0^{\mathrm{a}}$ & $94^{\mathrm{a}}$ \\
\hline $\mathrm{N}_{150}$ & & $119,8^{\mathrm{b}}$ & $24,6^{\mathrm{b}}$ & $39,3^{\mathrm{b}}$ & $74,7^{\mathrm{b}}$ & $91^{\mathrm{b}}$ \\
\hline $\mathrm{N}_{200}$ & & $130,9^{\mathrm{a}}$ & $28,7^{\mathrm{a}}$ & $45,2^{\mathrm{a}}$ & $77,7^{\mathrm{a}}$ & $94^{\mathrm{a}}$ \\
\hline $\mathrm{C}^{1}$ & & $123,4^{b}$ & $25,7^{\mathrm{b}}$ & $40,6^{b}$ & $75,5^{\mathrm{a}}$ & $92^{\mathrm{a}}$ \\
\hline Fomix $^{2}$ & & $127,2^{\mathrm{a}}$ & $27,6^{\mathrm{a}}$ & $43,9^{\mathrm{a}}$ & $76,9^{\mathrm{a}}$ & $93^{\mathrm{a}}$ \\
\hline $2016 / 2017$ & & $120,5^{\mathrm{c}}$ & $24,6^{c}$ & $37,4^{\mathrm{b}}$ & $74,8^{\mathrm{b}}$ & $93^{\mathrm{a}}$ \\
\hline $2017 / 2018$ & & $124,0^{\mathrm{b}}$ & $26,7^{\mathrm{b}}$ & $45,1^{\mathrm{a}}$ & $77,5^{\mathrm{a}}$ & $95^{\mathrm{a}}$ \\
\hline $2018 / 2019$ & & $131,5^{\mathrm{a}}$ & $28,4^{\mathrm{a}}$ & $44,2^{\mathrm{a}}$ & $76,2^{\mathrm{a}}$ & $89^{\mathrm{b}}$ \\
\hline \multicolumn{2}{|c|}{ Średnia - Mean } & 125,3 & 26,6 & 42,2 & 76,2 & 92 \\
\hline
\end{tabular}

$C^{l}$ - kontrola - control, Fomix² - FoliQ Mikromix, Wartości oznaczone tą samą literą nie różnią się istotnie - Different letters in the same column indicate significant differences, $\mathrm{p} \leq 0.05$

Tabela 6

Zawartość mikroelementów w ziarnie pszenicy hybrydowej (średnia z lat 2016-2019).

Table 6 Microelements content in grain of hybrid wheat (mean for 2016-2019).

\begin{tabular}{|c|c|c|c|c|c|}
\hline $\begin{array}{l}\mathrm{Cz} \\
\text { Tre }\end{array}$ & $\begin{array}{l}\text { anik } \\
\text { ment }\end{array}$ & \multirow{2}{*}{$\begin{array}{l}\text { Żelazo } \\
\text { Iron }\end{array}$} & \multirow{2}{*}{$\begin{array}{l}\text { Miedź } \\
\text { Cooper }\end{array}$} & \multirow{2}{*}{$\begin{array}{l}\text { Cynk } \\
\text { Zinc }\end{array}$} & \multirow{2}{*}{$\begin{array}{c}\text { Mangan } \\
\text { Manganese }\end{array}$} \\
\hline \multirow{2}{*}{$\begin{array}{l}\text { Dawka azotu } \\
\mathrm{N} \text { rate }\left(\mathrm{kg} \cdot \mathrm{ha}^{-1}\right)\end{array}$} & $\begin{array}{l}\text { Nawożenie } \\
\text { dolistne }\end{array}$ & & & & \\
\hline & $\begin{array}{l}\text { Foliar fertilization } \\
\qquad\left(\mathrm{dm}^{3} \cdot \mathrm{ha}^{-1}\right)\end{array}$ & \multicolumn{4}{|c|}{$\mathrm{mg} \cdot \mathrm{kg}^{-1}$} \\
\hline \multirow{2}{*}{$\mathrm{N}_{150}$} & $\mathrm{C}^{1}$ & $52,11^{\mathrm{c}}$ & $2,95^{\mathrm{b}}$ & $38,22^{\mathrm{b}}$ & $29,41^{\mathrm{a}}$ \\
\hline & Fomix $^{2}$ & $52,38^{\mathrm{c}}$ & $3,42^{b}$ & $41,91^{\mathrm{a}}$ & $31,25^{\mathrm{a}}$ \\
\hline \multirow{2}{*}{$\mathrm{N}_{200}$} & $\mathrm{C}^{1}$ & $53,76^{\mathrm{bc}}$ & $3,84^{\mathrm{a}}$ & $38,68^{\mathrm{b}}$ & $31,02^{\mathrm{a}}$ \\
\hline & Fomix $^{2}$ & $56,34^{\mathrm{a}}$ & $4,56^{\mathrm{a}}$ & $40,33^{\mathrm{a}}$ & $30,92^{\mathrm{a}}$ \\
\hline $\mathrm{N}_{150}$ & & $52,25^{\mathrm{b}}$ & $3,19^{\mathrm{b}}$ & $40,07^{\mathrm{a}}$ & $30,33^{a}$ \\
\hline $\mathrm{N}_{200}$ & & $55,05^{\mathrm{a}}$ & $4,20^{\mathrm{a}}$ & $39,51^{\mathrm{a}}$ & $30,97^{\mathrm{a}}$ \\
\hline $\mathrm{C}^{1}$ & & $52,94^{b}$ & $3,40^{\mathrm{a}}$ & $38,45^{\mathrm{b}}$ & $30,22^{\mathrm{a}}$ \\
\hline Fomix $^{2}$ & & $54,36^{\mathrm{a}}$ & $3,99^{\mathrm{a}}$ & $41,12^{\mathrm{a}}$ & $31,09^{\mathrm{a}}$ \\
\hline $2016 / 2017$ & & $53,82^{\mathrm{b}}$ & $3,52^{\mathrm{b}}$ & $38,45 b$ & $30,38^{\mathrm{a}}$ \\
\hline $2017 / 2018$ & & $52,11^{\mathrm{b}}$ & $2,81^{b}$ & $39,28^{\mathrm{ab}}$ & $30,56^{\mathrm{a}}$ \\
\hline $2018 / 2019$ & & $55,02^{\mathrm{a}}$ & $4,62^{\mathrm{a}}$ & $41,65^{\mathrm{a}}$ & $31,02^{\mathrm{a}}$ \\
\hline \multicolumn{2}{|c|}{ Średnia - Mean } & 53,65 & 3,69 & 39,79 & 30,65 \\
\hline
\end{tabular}

$C^{l}$ - kontrola - control, Fomix ${ }^{2}$ - FoliQ Mikromix, Wartości oznaczone tą samą literą nie różnią się istotnie - Different letters in the same column indicate significant differences, $\mathrm{p} \leq 0.05$ 
Nie stwierdzono istotnego wpływu dawki $\mathrm{N}_{200}$ na przyrost ilości $\mathrm{Zn}$ i Mn w ziarnie pszenicy. Z badań Pszczółkowskiej i in. (2018) wynika, że zwiększone nawożenie azotem nie różnicowało koncentracji Zn i Mn w ziarnie pszenicy, a zawartość Fe była najwyższa dla dawki $120 \mathrm{~N} \mathrm{kgha}^{-1}$. Svečnjak i in. (2013) wykazali natomiast, że po aplikacji wzrastających dawek azotu ziarno zawierało najwięcej manganu, a najmniej cynku.

Dolistna aplikacja FoliQ Mikromix powodowała istotny wzrost $\mathrm{w}$ ziarnie pszenicy $\mathrm{w}$ stosunku do obiektu kontrolnego zawartości Fe i Zn, odpowiednio o 2,7 i $6,9 \%$. Natomiast nie modyfikowała koncentracji $\mathrm{Mn}$ i Cu. Jak podaje Zhang i in. (2010) dolistne nawożenie pszenicy azotem oraz aplikacja różnych form mikroelementowych nawozów dolistnych ma kluczowe znaczenie dla zwiększenia koncentracji zwłaszcza $\mathrm{Zn}$ i Cu w ziarnie pszenicy.

W badaniach wykazano, że ziarno pszenicy mieszańcowej zawierało najwięcej żelaza $(53,65 \mathrm{mg}$ $\left.\mathrm{kg}^{-1}\right)$, a najmniej miedzi $\left(3,69 \mathrm{mg}^{-1} \mathrm{~kg}^{-1}\right.$. Średnie zawartości Fe były wyższe od wartości oznaczonych przez Rachonia i Szumiło (2009) w ziarnie Triticum aestivum L. (30,9 $\left.\mathrm{mg} \cdot \mathrm{kg}^{-1}\right)$, Triticum durum Desf. (29,0-33,7 mg.kg-1) i Triticum spelta $\mathrm{L}$. $\left(32,2-33,9 \mathrm{mg} \mathrm{kg}^{-1}\right)$. Natomiast średnia ilość $\mathrm{Cu}$ była zbliżona do zawartości tego pierwiastka prezentowanej w badaniach Suchowilskiej i in. (2012) $3,50 \mathrm{mg} \mathrm{kg}^{-1}$. Średnie zawartości Zn (39,79 $\left.\mathrm{mg} \mathrm{kg}^{-1}\right)$ i Mn $\left(30,65 \mathrm{mgkg}^{-1}\right)$ w ziarnie pszenicy hybrydowej były wyższe od wartości oznaczonych przez Stępnia i Wojtkowiak (2015) w ziarnie form jarych i ozimych pszenicy. Należy jednak podkreślić, że różnica $\mathrm{w}$ zawartości pierwiastków u pszenic populacyjnych i mieszańcowych może być powodowana czynnikiem genetycznym, a ponadto porównywane badania prowadzono $\mathrm{w}$ różnych warunkach klimatyczno-glebowych.

Zawartość mikroelementów w ziarnie pszenicy była zmienna w latach badań. Na wpływ czynników środowiskowych na zawartość składników pokarmowych, w tym zwłaszcza Fe i Zn w ziarnie pszenicy zwraca uwagę Morgounov i in. (2007). Istotnie więcej $\mathrm{Fe}, \mathrm{Cu}$ i $\mathrm{Zn}$ w ziarnie stwierdzono w sezonie 2018/2019 o umiarkowanych opadach i wyższych miesięcznych temperaturach w okresie formowania ziarna. Zmienne warunki pogodowe podczas trzech lat badań, nie zmieniały zawartości Mn w ziarnie pszenicy.

\section{Wnioski}

1. Zastosowanie dawki azotu $\mathrm{N}_{200}$ w porównaniu do $\mathrm{N}_{150}$ powodowało wzrost plonu ziarna i zawartości w nim $\mathrm{Fe}$ oraz $\mathrm{Cu}$, obsady kłosów, badanych parametrów jakości ziarna, a także wartości wskaźników LAI, MTA i SPAD pszenicy hybrydowej.

2. Nawożenie dolistne w porównaniu do obiektu kontrolnego wpłynęło na istotny wzrost plonu ziarna oraz zawartości $\mathrm{Zn}$ i Fe wskaźnika SPAD, MTZ a także cech jakościowych (białko, gluten, wskaźnik sedymentacji).

3. Warunki pogodowe z mniejszą sumą opadów oraz wyższymi miesięcznymi temperaturami w okresie formowania i dojrzewania ziarna pszenicy powodowały obniżenie plonu ziarna i przyrost ilości białka, glutenu, $\mathrm{Fe}, \mathrm{Cu}$, oraz Zn w ziarnie.

\section{Źródło finansowania badań}

Środki finansowe Ministerstwa Edukacji i Nauki na działalność naukową Instytutu Nauk Rolniczych, Ochrony i Kształtowania Środowiska Uniwersytetu Rzeszowskiego.

\section{Literatura}

Bavec M., Vuković K., Grobelnik Mlakar S., Rozman Č., Bavec F., 2007. Leaf area index in winter wheat: response on seed rate and nitrogen application by different varieties. J. Cent. Eur. Agric. 8 (3), 337-342.

Biskupski A., Kaus A., Włodek S., Pabin J., 2007. Zróżnicowane nawożenie azotem a plonowanie i wybrane wskaźniki architektury łanu kilku odmian pszenicy jarej. Inżynieria Rolnicza. 3 (91), 29-36.

Faizy S.E.D., Mashali S.A., Youssef S.M., Elmahdy S.M., 2017. Study of wheat response to nitrogen fertilization, micronutrients and their effects on some soil available macronutrients. J. Sus. Agric. Sci. 43 (1), 55-64. https:// doi.10.21608/JSAS.2017.3491

Fotyma E., Bezduszniak D., 2000. Valuation of nitrogen nutritional status of winter cereals on the ground of leaf greenness index. Fragm. Agron. 17 (4), 29-45.

Gąsiorowska B., Makarewicz A., 2008. Wpływ nawożenia dolistnego na plony i jakość ziarna pszenicy jarej. Annales UMCS. Sec. E. 63 (4), 87-95.

Jarecki W., Bobrecka-Jamro D., Jarecka A., 2016. Reakcja pszenicy jarej na zróżnicowane nawożenie azotowe oraz dokarmianie dolistne. Acta Agrophysica. 23, 39-50.

Jarecki W., Buczek J., Bobrecka-Jamro D., 2014. Reakcja pszenicy jarej odmiany Kandela na zróżnicowaną intensywność uprawy. Fragm. Agron. 31 (3), 58-65.

Jarecki W.. Bobrecka-Jamro D., 2011. Reakcja pszenicy jarej odmiany Parabola na dolistne dokarmianie mocznikiem i Mikrokomplexem. Biul. IHAR. 262, 39-46.

Jaskulska I., Jaskulski D., Gałęzewski L., Knapowski T., Kozera W., Wacławowicz R., 2018. Mineral composition and baking value of the winter wheat grain under 
varied environmental and agronomic conditions. J. Chem. 1-7. https://doi. 10.1155/2018/5013825

Kara B., Mujdeci M., 2010. Influence of late-season nitrogen application on chlorophyll content and leaf area index in wheat. Sci. Res. Essays. 5, 2299-2303.

Klikocka H., Cybulska M., Barczak B., Narolski B., Szostak B., Kobiałka A., Nowak A., Wójcik E., 2016. The effect of sulphur and nitrogen fertilization on grain yield and technological quality of spring wheat. Plant Soil Environ. 62, 230-236. https://doi.10.17221/18/2016-PSE

Kulig B., Oleksy A., Zając T., 2009. Wpływ sposobu uprawy roli i nawożenia azotem na plonowanie pszenicy jarej. Fragm. Agron. 26 (4), 81-94.

Morgounov A., Gomez-Becerra H.F., Abugalieva A., Dzhunusova M., Yessimbekova M., Muminjanov H., Zelenskiy Y., Ozturk L., Cakmak I., 2007. Iron and zinc grain density in common wheat grown in central Asia. Euphytica. 155, 193-203. https://doi.10.1007/ s10681-006-9321-2

Mühleisen J., Piepho H-P., Maurer H.P., Longin C.F., Reif J.C., 2014. Yield stability of hybrids versus lines in wheat, barley, and triticale. Theor. Appl. Genet. 127, 309-316. https://doi.org/10.1007/s00122-013-2219-1

Olsen J., Weiner J., 2007. The influence of Triticum aestivum density, sowing pattern and nitrogen fertilization on leaf area index and its spatial variation. Basic Appl. Ecol. 8, 252-257.

Panasiewicz K., Koziara W., Sulewska H., 2009. Reakcja pszenicy ozimej Triticum durum Desf. odmiany Komnata na gęstość siewu i nawożenie azotem. Biul. IHAR. 253, 125-134.

Podolska G., 2008. Wpływ dawki i sposobu nawożenia azotem na plon i wartość technologiczną ziarna odmian pszenicy ozimej. Acta Sci. Pol. Agricultura. 7 (1), 57-65.

Pszczółkowska A., Okorski A., Olszewski J., Fordoński G., Krzebietke S., Chareńska A., 2018. Effects of pre-preceding leguminous crops on yield and chemical composition of winter wheat grain. Plant Soil Environ. 64, 592-596. https://doi.10.17221/340/2018-PSE

Rachoń L., Szumiło G., 2009. Comparison of chemical composition of selected winter wheat species. J. Elem.14,
135-146.

Rharrabti Y., Royo C., Villegas D., Aparicio N., Gracia del Maoral L. F., 2003. Durum wheat quality in Mediterranean environments I. Quality expression under different zones. latitudes and water regime acsross Spain. Field Crops Res. 80, 123-131.

Skudra I., Ruza A., 2016. Winter wheat grain baking quality depending on environmental conditions and fertilizer. Agron. Res. 14, 1460-1466.

Stępień A., Wojtkowiak K., 2015. Effect of meat and bone meal on the content of microelements in the soil and wheat grains and oilseed rape seeds. J. Elem. 20, 999-1010. https://doi.10.5601/jelem.2015.20.1.811

Suchowilska E., Wiwart M., Kandler M., Krska R., 2012. A comparison of macro- and microelement concentrations in the whole grain of four Triticum species. Plant Soil Environ. 58,141-147. http://dx.doi.org/10.17221/688/ 2011-PSE

Sulewska H., Koziara W., Panasiewicz K., Niewiadomska A., 2011. Reakcja pszenicy ozimej i jęczmienia jarego na nawożenie PRP SOL. J. Res. Appl. Agric. Eng. 56 (4), 129-133.

Svečnjak Z., Jenel M., Bujan M., Vitali D., Dragojevic V.I., 2013. Trace element concentrations in the grain of wheat cultivars as affected by nitrogen fertilization. Agr. Food Sci. 22, 445-451. https://doi.org/10.23986/afsci.8230

Whitford R., Fleury D., Reif J.C., Garcia M., Okada T., Korzun V., Langridge P., 2013. Hybrid breeding in wheat: technologies to improve hybrid wheat seed production. J. Exp. Bot. 64, 5411-5428. https://doi.org/10.1093/jxb/ert333

Zeidan M.S., Mohamed M.F., Hamouda H.A., 2010. Effect of foliar fertilization of $\mathrm{Fe}, \mathrm{Mn}$ and $\mathrm{Zn}$ on wheat yield and quality in low sandy soils fertility. World J. Agric. Sci. 6, 696-699.

Zhang Y., Song Q., Jan Y., Tang J., Zhao R., Zhang Y., He Z., Zou C., Ortiz-Monasterio I., 2010. Mineral element concentrations in grains of Chinese wheat cultivars. Euphytica. 174, 303-313. https://doi.10.1007/s10681-009-0082-6

Zhao Y., Zeng J., Fernando R., Reif J.C., 2013. Genomic prediction of hybrid wheat performance. Crop Sci. 53, 802-810. https://doi.org/10.2135/cropsci2012.08.0463 